\title{
Psychological Impact of Mizoram Insurgency
}

\author{
Dr. Zoramhmangaihzuali Khiangte ${ }^{1 *}$
}

\section{ABSTRACT}

This study was designed to investigate the psychological effect of insurgency in the Mizo, caused by the 20 years insurgency in Mizoram. To meet the objectives 200 Mizo participants were randomly selected, who had experienced that stressful situations at different levels of exposures to the stressful episodes. The study examines level of anxiety, depression, angerhostility, somatic-concern and frustration of the insurgency effected people in Mizoram. It was found that those who had experience combat at first hand and fatal episode were the most vulnerable to psychological problems.

Keywords: Insurgency, Fatal, Volunteer, Stress, Anxiety, Depression, Frustration.

Insurgency has existed throughout history but ebbed and flowed in strategic significance. Today it became the common household name as the media flashes about it every day. The Mizo has their fair share of it for more than 25 years, leaving physical and psychological bruises. From the many interviews taken, Nationalism appears to be the guiding force for the insurgency in Mizoram.

The Mizo had a historic control over their Mizoram, and the insurgency may be an action of prevention of their personal space or territory from invader or who annexed Mizoram to British Empire (British India) and that anger remains in the inner feeling and just finds a time to act out violently their heightened anxiety.

According to the study done by Prof. Zokaitluangi and Prof. C. Lalfamkima Varte (2011) Acculturation seems to be one of the major reason behind the Mizo movement.

Acculturation leads to stress, frustration, anger, psychosomatic symptoms (William \& Berry, 1991) and negative psychological consequences (Park, 1928) amongst the Mizo. Which then give rise to formation of high group bond and the feeling of Nationalism to suffice their needs? Nationalist group, Mizo National Front was formed to meet the need of the people.

\footnotetext{
${ }^{1}$ Guest Lecturer, Department of Psychology, Mizoram University, Aizawl, Mizoram, India

*Responding Author

(C) 2016 I Z Khiangte; licensee IJIP. This is an Open Access Research distributed under the terms of the Creative Commons Attribution License (http://creativecommons.org/licenses/by/2.0), which permits unrestricted use, distribution, and reproduction in any Medium, provided the original work is properly cited.
} 
In order to reduce and cope with their negative emotions they need to find ways to let out their frustration and anger, so they used aggression and hostility towards the intruders of their territory. So acculturation was the main issue that leads to the feeling of Nationalism, and Nationalism was the driving force behind the rebellious behavior and the feeling of negativity towards others arises. Negative states were associated with stress: irritability, anger, frustrations, embarrassment, depression, helplessness, hostility and anxiety.

Several researches provided sufficient evidences that the war and conflict is accompanied by psychological and physical psychosomatic symptoms, identity confusion, general anxiety and depression (Jones, 1985; Norbury, 1930; Elder \& Clipp, 1988)

It is self-evident that stress will play a far more important role during a war-situation, when the demands, which are made on the population in general, and on the combatants in particular, exceed those normally experienced.

The impact of war are terrible, many may suffer immediate pain, horror, destruction and even death. Mental anguish during and after warfare should not be under estimated compared to more visible wounds. The invisible wounds may result from the combat itself, living in or close to a combat zone, personal or simply exposure to war from afar as the member of a warring population, etc. Adrenaline which promotes survival in the short term fatigues and wears dangerously on people in the long term. The severe combat stress frequently produces psychopathology and substance abuse.

War (which include both wars waged between countries and conflicts within countries) has a catastrophic effect on the health and wellbeing of nations. Studies have shown that conflict situations cause more mortality and disability than any major disease. War destroys communities and families and often disrupts the social and economic development of the people and worst, the long-term physical and psychological damage it left behind.

\section{Objectives and Hypotheses}

The objectives of this study are to evaluate the anxiety, depression and frustration level of the insurgents (volunteers) with Fatal experience (Fatal) and Non-Fatal experience (Non-Fatal) for comparison with civil (non-volunteers) participants with Fatal experience (Fatal) and Non-Fatal experience (Non-Fatal).

The study examines level of anxiety, depression, anger-hostility, somatic-concern and frustration-effects, which is the behavior mechanism triggered by frustration, of the insurgency effected people in Mizoram.

It was hypothesized that - The Insurgents (volunteers) may exhibit greater anxiety, depression and frustration scores than civilians (non-volunteers); 


\section{METHODOLOGY}

\section{Sample:}

This study investigated 'Psychological impact of Mizoram insurgency' and explicates the level of anxiety, depression, frustration caused by the insurgency among those volunteers and nonvolunteers who experienced fatal and non-fatal situations. The participant, i.e. The Mizo, who were selected for the present study experienced the Insurgency from the onset (1966) till the 'Peace Accord' was signed (1986) between the MNF and the Government of India.

To meet the objectives, 200 Mizo participants between 50-70 years of age experiencing the insurgency in Mizoram were randomly selected from different part of Mizoram to serve as subjects for the present study. The structured interview questionnaire pertaining to the perceived causes and impact of insurgency in Mizoram based on psychological measures of anxiety, depression, frustration and coping were administered to determine the psychological impact of insurgency in Mizoram.

The participants were randomly selected from different part of Mizoram affected by the MNF movement, with due care of extraneous variables to identify true representation. Lists of people who are a member of PAMRA, Ex-MNA, Widow of MNA and Mizoram Elder Association (MUP - Mizoram Upa Pawl) who had experienced the Mizoram insurgency were obtained. From these lists the participants were randomly selected. The 'Volunteer' with consideration of 'Fatal' and 'Non-Fatal' were selected from the list of Ex-MNF (PAMRA and MNA - Association on Hnam Run, Office of the MNF Party Headquarters.). Following the same procedure of the sample selection, the 'Non-volunteer' were selected from the list of the members of Mizoram Elder Association (MUP) and the Widows of MNA (Association of Hnam Run). 'Gender' was not included in the design as very few members of female volunteers could be identified.

\section{Psychological tools:}

1. Symptom Questionnaire (SQ; Kellner, 1987): The Symptom Questionnaire (SQ) is a yes/no questionnaire with brief and simple items. It contains state scales of depression (D), anxiety (A), anger-hostility (AH), and somatic symptoms (S).

2. Frustration Test (Chauhan \& Tiwari, 1972): This test consists of 40 items out of which each four modes- Regression (R), fixation (F), resignation (RS) and aggression (A) of frustration has 10 items each.

\section{Design of the study:}

$2 \times 2$ factorial design (2 Volunteer $\times 2$ Fatal) was employed to highlight the independent and interaction effects of the independent variables on the dependent measures. 


\section{RESULTS \& DISCUSSION}

From the data collected, from the samples of volunteers and non-volunteers a statistical analyses was done and the result on Table- 1 and Table- 2 indicated that there exist significant differences between the groups i.e. the insurgents (volunteers) with Fatal experience (Fatal) and Non-Fatal experience (Non-Fatal) and civilians (non-volunteers) participants with Fatal experience (Fatal) and Non-Fatal experience (Non-Fatal).

Table - 1

\begin{tabular}{|c|c|c|c|c|c|c|c|c|c|}
\hline \multicolumn{10}{|c|}{ Mean, Standard Deviation, Skewness and Kurtosis } \\
\hline \multicolumn{6}{|c|}{ Volunteer (Fatal) } & \multicolumn{4}{|c|}{ Non Volunteer (Fatal) } \\
\hline Variables & $\mathbf{N}$ & Mean & SD & $\begin{array}{c}\text { Skewness } \\
\mathrm{SE}=.34\end{array}$ & $\begin{array}{c}\text { Kurtosis } \\
\text { SE }=.66\end{array}$ & Mean & SD & \begin{tabular}{|c|} 
Skewness \\
SE $=.34$
\end{tabular} & $\begin{array}{c}\text { Kurtosis } \\
\text { SE }=.66\end{array}$ \\
\hline FT (RG) & 50 & 33.16 & 2.86 & -.43 & .72 & 26.46 & 2.49 & 1.39 & 5.48 \\
\hline FT (FX) & 50 & 33.16 & 2.86 & -.43 & .72 & 26.52 & 2.49 & 1.29 & 5.43 \\
\hline FT (RSG) & 50 & 32.06 & 2.89 & .33 & .09 & 43.18 & 3.03 & .40 & -.01 \\
\hline FT (AG) & 50 & 37.88 & 3.08 & -.18 & -.54 & 27.62 & 3.65 & -.02 & -.99 \\
\hline SQ (A) & 50 & 19.54 & 1.96 & -.67 & -.42 & 13.92 & 1.90 & .14 & .31 \\
\hline SQ (D) & 50 & 18.80 & 1.61 & -.23 & -.91 & 12.68 & 2.00 & -1.20 & 1.52 \\
\hline SQ (SC) & 50 & 9.82 & 1.39 & .28 & -.87 & 15.70 & 1.23 & .54 & .75 \\
\hline $\mathrm{SQ}(\mathrm{AH})$ & 50 & 19.08 & 1.99 & .06 & -.37 & 13.50 & .95 & .00 & -.86 \\
\hline \multicolumn{6}{|c|}{ Volunteer (Non-Fatal) } & \multicolumn{4}{|c|}{ Non Volunteer (Non-Fatal) } \\
\hline Variables & $\mathbf{N}$ & Mean & SD & $\begin{array}{c}\text { Skewness } \\
\mathrm{SE}=.34\end{array}$ & $\begin{array}{c}\text { Kurtosis } \\
\mathrm{SE}=.66\end{array}$ & Mean & SD & \begin{tabular}{|c|} 
Skewness \\
SE $=.34$
\end{tabular} & $\begin{array}{c}\text { Kurtosis } \\
\text { SE }=.66\end{array}$ \\
\hline$\overline{\text { FT (RG) }}$ & 50 & 29.76 & 3.13 & .103 & .63 & 21.26 & 2.33 & -.22 & -.99 \\
\hline FT (FX) & 50 & 29.76 & 3.16 & .100 & .49 & 21.40 & 2.26 & -.38 & -.77 \\
\hline FT (RSG) & 50 & 38.06 & 2.316 & .551 & -.21 & 47.48 & 3.82 & -.78 & 1.02 \\
\hline FT (AG) & 50 & 31.28 & 4.62 & -.642 & .21 & 23.92 & 4.43 & 19 & -1.09 \\
\hline SQ (A) & 50 & 16.80 & 1.87 & -1.133 & 2.46 & 11.72 & 2.11 & .69 & .07 \\
\hline SQ (D) & 50 & 15.62 & 1.86 & .011 & 1.74 & 10.10 & 1.50 & -.10 & -.62 \\
\hline SQ (SC) & 50 & 12.62 & 1.62 & .472 & 4.78 & 18.66 & 1 & -.64 & .11 \\
\hline SQ (AH) & 50 & 15.90 & 1.67 & -.713 & .71 & 9.60 & 1.73 & -.28 & -.10 \\
\hline
\end{tabular}


Table - 2

\begin{tabular}{|c|c|c|c|c|c|c|c|c|c|}
\hline \multirow[t]{2}{*}{ Variables } & \multicolumn{5}{|c|}{$\begin{array}{l}\text { ANOVA for } 2 \text { x } 2 \text { factorial design } \\
\quad \text { ( } 2 \text { Volunteer } x 2 \text { Fatal). } \\
\text { Tests of Between-Subjects Effects }\end{array}$} & \multicolumn{4}{|c|}{$\begin{array}{c}\text { Levene's Test of Equality } \\
\text { of Error Variances }\end{array}$} \\
\hline & Source & df & $\mathbf{F}$ & Sig. & $\begin{array}{c}\text { Partial } \\
\text { Eta } \\
\text { Squared }\end{array}$ & $\mathbf{F}$ & df1 & df2 & Sig. \\
\hline SQ (Anxiety) & $\begin{array}{l}\text { Volunteer } \\
\text { Fatal } \\
\text { Volunteer x Fatal }\end{array}$ & $\begin{array}{l}1 \\
1 \\
1\end{array}$ & $\begin{array}{r}370.94 \\
79.06 \\
.94\end{array}$ & $\begin{array}{l}.00 \\
.00 \\
.33\end{array}$ & $\begin{array}{l}.65 \\
.28 \\
.01\end{array}$ & .71 & 3 & 196 & .55 \\
\hline SQ (Depression) & $\begin{array}{l}\text { Volunteer } \\
\text { Fatal } \\
\text { Volunteer x Fatal }\end{array}$ & $\begin{array}{l}1 \\
1 \\
1\end{array}$ & $\begin{array}{r}548.53 \\
134.32 \\
1.45\end{array}$ & $\begin{array}{l}.00 \\
.00 \\
.22\end{array}$ & $\begin{array}{l}.73 \\
.40 \\
.01\end{array}$ & .61 & 3 & 196 & .61 \\
\hline $\begin{array}{l}\text { SQ (Somatic } \\
\text { Concern) }\end{array}$ & $\begin{array}{l}\text { Volunteer } \\
\text { Fatal } \\
\text { Volunteer x Fatal }\end{array}$ & $\begin{array}{l}1 \\
1 \\
1\end{array}$ & $\begin{array}{r}786.01 \\
183.53 \\
.14\end{array}$ & $\begin{array}{l}.00 \\
.00 \\
.70\end{array}$ & $\begin{array}{l}.80 \\
.48 \\
.00\end{array}$ & 1.71 & 3 & 196 & .17 \\
\hline SQ (Anger Hostility) & $\begin{array}{l}\text { Volunteer } \\
\text { Fatal } \\
\text { Volunteer x Fatal }\end{array}$ & $\begin{array}{l}1 \\
1 \\
1\end{array}$ & $\begin{array}{r}656.52 \\
233.17 \\
2.41\end{array}$ & $\begin{array}{l}.00 \\
.00 \\
.12\end{array}$ & $\begin{array}{l}.77 \\
.54 \\
.01\end{array}$ & 5.43 & 3 & 196 & .00 \\
\hline FT (Regression) & $\begin{array}{l}\text { Volunteer } \\
\text { Fatal } \\
\text { Volunteer x Fatal }\end{array}$ & $\begin{array}{l}1 \\
1 \\
1\end{array}$ & $\begin{array}{r}389.87 \\
124.80 \\
5.46\end{array}$ & $\begin{array}{l}.00 \\
.00 \\
.02\end{array}$ & $\begin{array}{l}.66 \\
.39 \\
.03\end{array}$ & 1.23 & 3 & 196 & .29 \\
\hline FT (Fixation) & $\begin{array}{l}\text { Volunteer } \\
\text { Fatal } \\
\text { Volunteer x Fatal }\end{array}$ & $\begin{array}{l}1 \\
1 \\
1\end{array}$ & $\begin{array}{r}381.14 \\
122.96 \\
5.01\end{array}$ & $\begin{array}{l}.00 \\
.00 \\
.02\end{array}$ & $\begin{array}{l}.66 \\
.38 \\
.02\end{array}$ & 1.79 & 3 & 196 & .15 \\
\hline FT (Resignation) & $\begin{array}{l}\text { Volunteer } \\
\text { Fatal } \\
\text { Volunteer x Fatal }\end{array}$ & $\begin{array}{l}1 \\
1 \\
1\end{array}$ & $\begin{array}{r}562.52 \\
141.45 \\
3.85\end{array}$ & $\begin{array}{l}.00 \\
.00 \\
.05\end{array}$ & $\begin{array}{l}.74 \\
.42 \\
.02\end{array}$ & 3.71 & 3 & 196 & .01 \\
\hline FT (Aggression) & $\begin{array}{l}\text { Volunteer } \\
\text { Fatal } \\
\text { Volunteer x Fatal }\end{array}$ & $\begin{array}{l}1 \\
1 \\
1\end{array}$ & $\begin{array}{r}243.26 \\
83.12 \\
6.59\end{array}$ & $\begin{array}{l}.00 \\
.00 \\
.01\end{array}$ & $\begin{array}{l}.55 \\
.29 \\
.03\end{array}$ & 3.54 & 3 & 196 & .02 \\
\hline
\end{tabular}

The results findings, as seen on Figure 1, indicated that, volunteers who had fatal experiences were highest on Anxiety, Depression and Anger-Hostility followed by volunteers with no fatal experiences then comes non-volunteers with fatal experiences and non-volunteers with no fatal experiences were found to have lowest Anxiety, lowest Depression and lowest Anger-Hostility as compared to the other groups. 


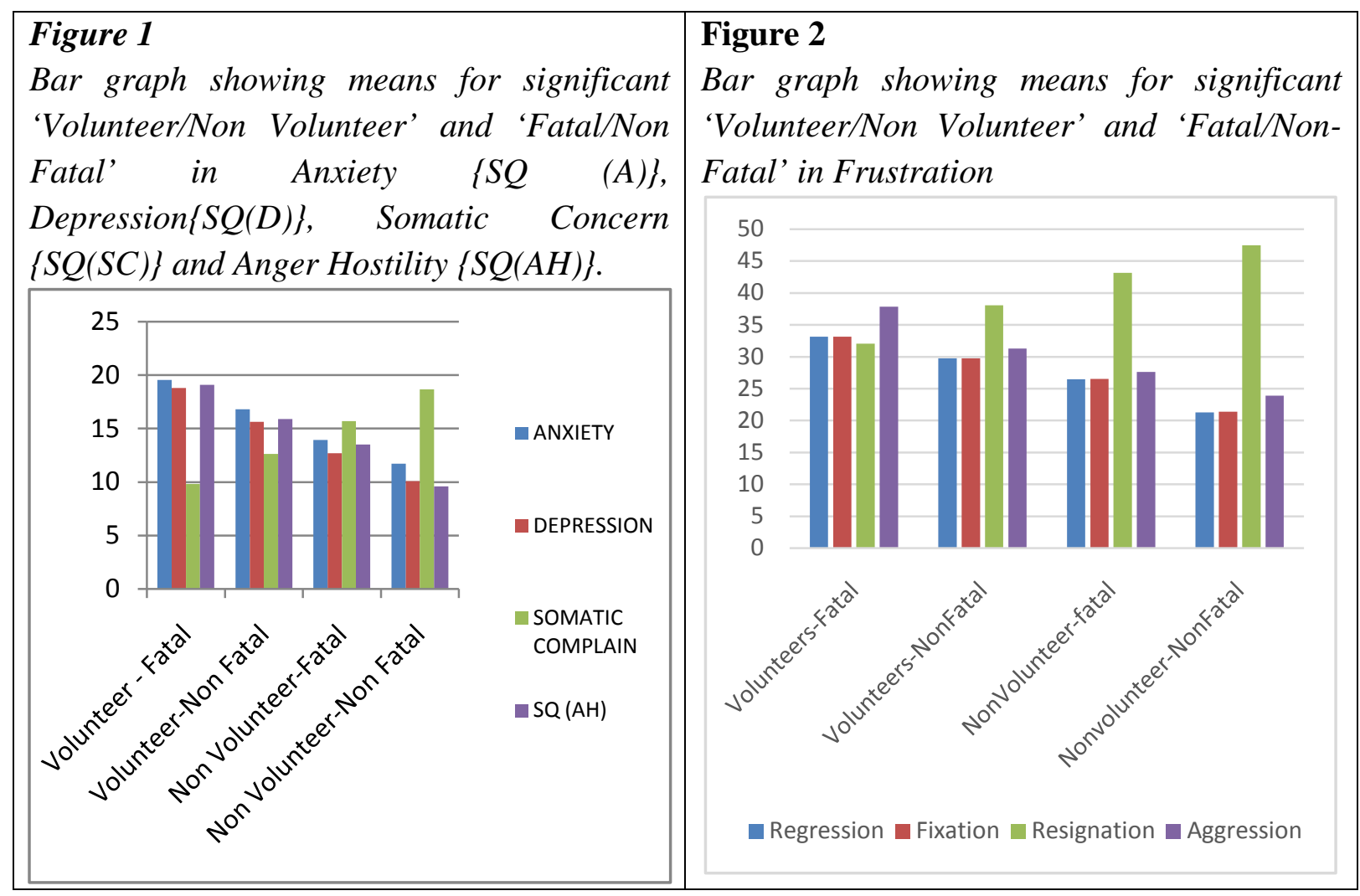

Somatic complain were found to be highest amongst the non-volunteers without fatal experiences followed by non-volunteers with fatal experiences then volunteers with no fatal experiences and volunteer who had fatal experiences even though they had experiences highest physical and mental strains somatic complains is not the dominating factor in their psychological health. The reason behind the dominance of somatic complain amongst the non-volunteer with no fatal experiences may be because of the unconscious defense mechanism by which the anxiety that stems from intrapsychic conflict is converted and expressed in somatic symptoms.

The frustration scores also indicated that frustration as a whole is found to be highest amongst the volunteer with fatal experience and lowest amongst the Non-volunteer with No-Fatal experience except for the Frustration-Resignation where Non-volunteer with No Fatal experience participants scores the highest (Figure 2). In resignated behavior we obtain extreme elimination of needs, no plans, no definite relations to the future; either no hopes at all or hopes which are not taken seriously (Zawadski and Lazaresfeld, 1935). On all other frustration behavior mechanism Insurgents seems to have higher scores as compared to the civilians and the scores are at the concerning level. This shows that amongst the insurgents expression of frustration in the mode of aggression was concerning high, so does the Frustration-Fixation which is a defense against anxiety by stopping the process of development (Symonds, 1946) and also FrustrationRegression which is an "acting out” i.e. resistance in analysis against the remembering of painful ideas. This results shows that frustration get expressed in various modes at concerning high level amongst the Insurgents during insurgency 
The results indicated that 'Volunteer' exhibited greater anxiety, depression and frustration scores as compared to 'Non Volunteer'; which is in aligned with the theoretical expectation (hypothesis) set forth for the study (Insurgents may exhibit greater mean scores than Civilian).

\section{CONCLUSION}

It can be seen from the results those who are first hand combatant and those who experience fatal episodes are more likely to develop psychological stress, and mental problem. This finding conforms to many previous studies done by researcher such as Elder \& Clipp (1988); Archibald, Long, Miller, and Tuddenham (1962); Jones (1985); Norbury (1930); etc.

War, natural disaster, riot etc., leaves us with huge devastations. Everyone can see it with our naked eye the destructions and physical wound war brought and People accept the fact that this injury could kill, forever disfigure the person and affect them physically for the rest of their life. But often we tend overlooked at the mental pain it caused. Physical war wounds, while extremely devastating, often overshadow psychological war wounds when those can cause much more devastation than physical war wounds themselves. It is hard for people to think of psychological trauma as an injury; but it is definitely an injury and one that deserves acknowledgement.

People who are psychologically damaged will have to deal with the consequences of their psychological injuries for the rest of their life, whether their symptoms are slight or severe. If care is not given it will forever haunt them until the day they die.

Results based on the retroactive report was the major limitation of this study as many psychological factors may interfere in one's course of life which may distort or shadowed one's original psychological condition. But still, this kind of traumatic life event which involve war and combat, where many died and many injured, and everyone it effected taste the cold shiver, will forever be welded on to them. This is evident in the quotation of many of the participants of this study - "You can never forget this kind of experience, it was very terrifying and distressing".

\section{REFERENCES}

Archibald HC, Long DM, Miller C, Tuddenham RD. (1962). “Gross stress reactions in combat: A 15-year follow-up”. Am J Psychiatry. 119:317-322.

Elder, G.H and Clipp,E. C. (1988). "Combat Experience and Emotional Health: Impairment and Resilience in Later Life”. Journal of Personality, Volume 57, Issue 2, pages 311-341.

Jones FD.(1985). “Psychiatric lessons of low-intensity wars.”Ann Med Milit Fenn [Finland] 60:128-134.

Norbury FB.(1953). “Psychiatric admissions in a combat division”. US Army Med Bull Far East. July .130-133.

Park, R.E. (1928). “Human Migration and the marginal man”. The American Journal of Sociology. 
Symonds, P.M. "Dynamics Of Human Adjustment". Appleton-Century Company. Inc. New York, 1946.

Zawadski, B., \& Lazarsfeld, P. F. (1935). “The psychological consequences of unemployment”. Journal of Social Psychology, 6, 224-251.

Zokaitluangi and Varte, C.L. (2011). "The Causes and Effect of Mizoram Insurgency". Unpublished UGC Major Project, Department of Psychology, Mizoram University.

Williams, C. L., \& Berry, J. W. (1991). "Primary prevention of acculturative stress among refugees: Application of psychological theory and practice”. American Psychologist. Vol. 46(6), Jun 1991, 632-641. 